\title{
Feline Leukemia Virus Detection in Corneal Tissues of Cats by Polymerase Chain Reaction and Immunohistochemistry
}

\author{
by
}

Ian Phillip Herring

Thesis submitted to the Faculty of the Virginia Polytechnic Institute and State University in partial fulfillment of the requirements for the degree of

\author{
Master of Science \\ in \\ Veterinary Medical Sciences
}
Gregory Troy, Chair
J. Phillip Pickett
Erin Champagne
Thomas Toth

April 27, 1998

Blacksburg, Virginia

Keywords: Cornea, Feline Leukemia Virus, Polymerase Chain Reaction, Immunohistochemistry

Copyright 1998, Ian Phillip Herring 
Feline Leukemia Virus Detection in Corneal Tissues of Cats by Polymerase Chain Reaction and Immunohistochemistry

\author{
Ian Phillip Herring
}

\begin{abstract}
Corneal transplantation carries a high rate of success in the domestic cat and is an indicated treatment for specific corneal diseases in this species. The potential for iatrogenic transmission of viral diseases is a well-recognized problem in human corneal transplantation programs and screening donors for certain diseases is routine. Feline leukemia virus (FeLV) is a common agent of disease in domestic cats and available blood tests are highly effective in identification of infected individuals. This study investigates the presence of FeLV within corneal tissues of FeLV infected cats.
\end{abstract}

Seventeen cats were identified to be positive for serum p27 antigen by enzymelinked immunosorbent assay (ELISA). Twelve of these individuals were found to be positive on peripheral blood by immunofluorescent antibody (IFA) testing. Seventeen ELISA negative cats were identified to serve as negative controls. Full thickness corneal specimens were collected from all subjects and analyzed for the presence of FeLV proviral DNA and gp70 antigen by polymerase chain reaction (PCR) and immunohistochemical (IHC) testing, respectively.

Eleven (64.7\%) positive corneal PCR results were obtained from 17 ELISA positive cats. Of 12 cats which were both ELISA and IFA positive on peripheral blood, 10 (83.3\%) had positive corneal PCR results. All corneal tissues from ELISA negative subjects were PCR negative. IHC staining of corneal sections revealed the presence of FeLV gp70 in corneal tissues of nine (52.9\%) ELISA positive cats. Of the 12 cats which were both ELISA and IFA positive on peripheral blood, 8 (66.7\%) had positive corneal IHC results. Positive IHC staining was localized to the corneal epithelium. Corneal tissues of all ELISA negative cats and all IFA negative cats were negative on IHC testing.

This study reveals FeLV to be present within the corneal epithelium of some FeLV infected cats. Screening potential corneal donors for this virus is warranted.

This work was funded by grants from the American College of Veterinary Ophthalmologists, the Virginia Veterinary Medical Association Pet Memorial Fund, and the DSACS Quick Response Fund. 


\section{Acknowledgments}

I would like to acknowledge the assistance of other individuals that helped in the completion of this project.

To my graduate committee members: Dr. Greg Troy, Dr. Phil Pickett, Dr. Erin Champagne, and Dr. Thomas Toth for assisting in the design and execution of this research, and for assisting in the preparation of this thesis;

To VTH clinicians, private practitioners, and the Roanoke and Harrisonburg SPCA's for assisting in collection of corneal tissues;

To Mr. Shawn Walker, M.S. graduate student at the Virginia Maryland Regional College of Veterinary Medicine in Dr. Thomas Toth's lab for assisting in learning PCR technology;

To Mr. John McQuiston of the CMIDD Staff at the Virginia Maryland Regional College of Veterinary Medicine for assisting in PCR technique development and DNA sequencing of PCR products;

To Ms. Megan Irby and Ms. Rachel Bethard of the Physiology and Clinical Research Lab at the Virginia Maryland Regional College of Veterinary Medicine for their assistance in sample collection;

To Dr. Debra Haines, Department of Microbiology, College of Veterinary Medicine, Saskastoon, Canada for developing immunohistochemical techniques used in staining corneal samples, and for reading the cornea slides;

To Dr. Francois Elvinger, Department of Large Animal Clinical Sciences, Virginia Maryland Regional College of Veterinary Medicine for assisting with statistical analysis of test results. 


\section{Table of Contents}

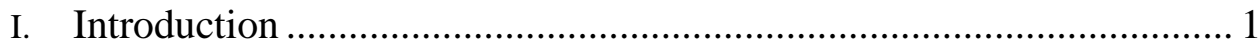

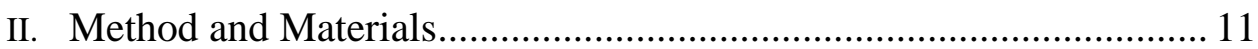

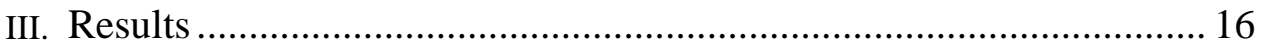

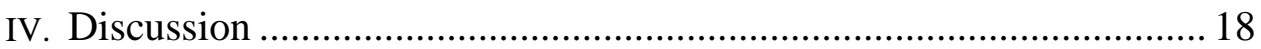

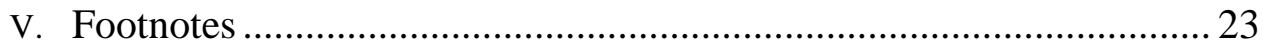

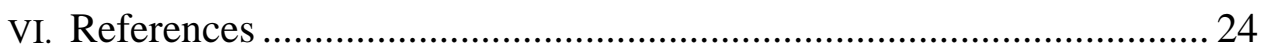

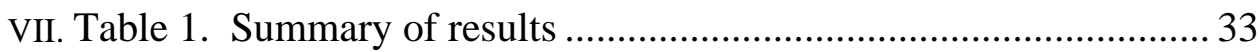

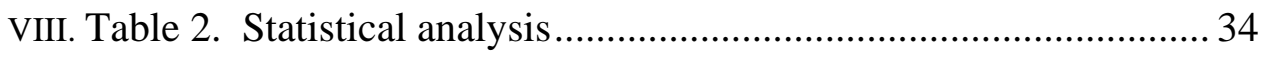

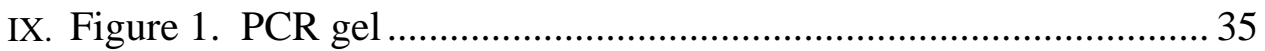

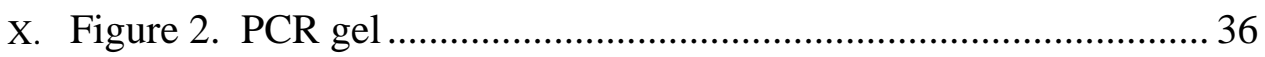

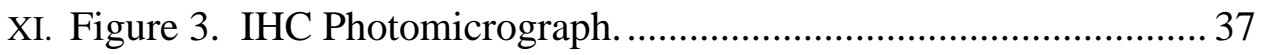

XII. Figure 4. IHC Photomicrograph............................................... 38

XIII. Figure 5. IHC Photomicrograph................................................ 39

XIV. Figure 6. IHC Photomicrograph ............................................. 40

XV. Appendix A.................................................................... 41

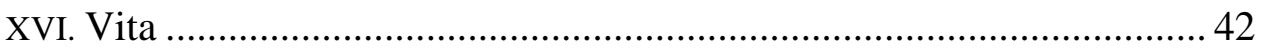




\section{Introduction}

Corneal transplantation, more appropriately termed penetrating keratoplasty (PK), has become a successful clinical procedure used in human beings. This success follows over 150 years of failures due to a variety of complications. De Quengsy first introduced the concept of an artificial cornea in 1789 using glass similar to a watch crystal and substituting it for a scarred cornea, but there is no record of any actual attempt of this procedure in humans. ${ }^{1}$ In 1796, Erasmus Darwin proposed the removal of a small portion of a clouded cornea with some sort of trephine and theorized the site would heal with a transparent scar. ${ }^{2}$ Reisenger is credited with the concept that human corneal tissue could be replaced by corneal tissue from an animal, coining the term "keratoplasty" for the procedure. ${ }^{3}$ Reisenger performed transplants in chickens and rabbits, although the success of these procedures is unknown.

The first successful corneal homograft was reported by Bigger in 1835, when he transplanted a clear cornea from one gazelle to another gazelle with a diseased cornea. 4 Not realizing the importance of using homologous tissue to his success, he suggested in the same publication that pig corneal tissue could be used to replace human corneal tissue. The first human corneal transplant procedure was performed in 1838, using a

pig's cornea as donor tissue. ${ }^{5}$ This attempt failed primarily due to sepsis and graft rejection because of use of heteroplastic material. Power, in 1872, declared that homoplastic material was necessary for successful corneal transplants and implied the corneal endothelium was also important to a successful outcome. 6 Von Hippel reported a successful heteroplastic lamellar graft in 1888 and described a circular trephine which he developed for use in this procedure. ${ }^{7}$ A successful penetrating keratoplasty using homologous corneal tissue in a human was performed in 1905 when Dr. Eduard Zirm, using von Hippel's trephine, transplanted clear corneal buttons from an 11 year old boy to a man blinded by alkali corneal burns. ${ }^{8}$ The graft in the recipient's right eye failed, but the left graft remained clear enough to have useful function from the eye. Since this 
report, advances in surgical technique, asepsis, immunomodulation, and tissue storage technology have made corneal transplantation a common and successful procedure. For certain corneal diseases, long term graft clarity is achieved in greater than $90 \%$ of human patients, while for patients with active inflammatory disease the success rate may decrease to $50-80 \% .^{9}$

Historical evidence of corneal transplantation in domestic species is sparse. Experimental and clinical reports of the technique in dogs suggest variable success with the procedure. Jensen reported results of lamellar grafts and partial PK in 37 dogs in 1963. 10 Of 24 eyes in which PK was performed, nine had moderate to good results. Two dogs were euthanized shortly post-operatively for unrelated reasons and 13 grafts were considered failures. In 1973, a report of auto- and allografts performed on eight Beagles was published. ${ }^{11}$ Results in this study were poor, but the type of suture material used and lack of immunosuppressive therapy probably influenced these results. Keller et al., reported results of corneal and scleral grafts in five clinical canine cases in 1973.12 Two of these were PK procedures and both were considered successful. PK has also shown promise as a therapy for primary corneal endothelial dystrophy. ${ }^{13}$ Hacker reported successful results in both dogs and cats when frozen allograft tissue was used for tectonic grafting. ${ }^{14}$ A recent case series describing PK for management of corneal stromal abscessation in horses suggests that it is a useful therapeutic modality for this disease. 15

Success rates for PK in the cat appear to be excellent. Experimental results with feline PK are on par with human beings with regard to a low incidence of rejection and resultant graft clarity. 16,17 For this reason, the cat serves as an appropriate model for human corneal transplantation. Published clinical studies in veterinary medicine describing PK are sparse. ${ }^{14}$ Personal communications with several veterinary ophthalmologists indicate that corneal transplantation is a useful technique for treatment of numerous diseases of the cornea in this species. ${ }^{\text {a-d }}$ Indications for PK in the cat include 
endothelial dystrophy/degeneration, corneal sequestrae, bullous keratopathy, corneal perforation, and scarring from trauma.

Despite advances in knowledge and technique and resultant increases in success rates in human PK, there still exist areas of concern. One important issue is that of disease transmission via the allograft. Two sources of infection are possible with PK. The less common, but potentially more devastating problem, is the transmission of a viral disease harbored by the donor. Alternatively, graft material can become septic during tissue harvesting, handling, and storage with subsequent inoculation and infection of the recipient. 18 Several bacterial and fungal diseases have been transmitted by PK resulting in loss of vision, the involved eye, or life. ${ }^{19}, 20$

Numerous viral agents have been detected in human corneal tissue and include rabies(Zaaidman), human immunodeficiency virus (HIV), hepatitis B, herpes simplex, cytomegalovirus, varicella-zoster, Epstein-Barr virus, and adenovirus. ${ }^{21-31}$ Three human viral diseases, rabies, hepatitis B, and the Creutzfeldt-Jakob agent, have reportedly been transmitted via PK. ${ }^{32-34}$ Several cases of rabies virus transmission via PK are documented. One case occurred in the U.S. and all cases were fatal. 32 A 55 year old woman received a corneal transplant from a donor with autopsy confirmed CreutzfeldtJakob disease. She subsequently developed neurologic signs and died with a confirmed pathologic diagnosis of Creutzfeldt-Jakob disease. ${ }^{34}$ Human hepatitis B virus has long been considered to be potentially transmissible via PK. Hoft and associates reported two cases of transmission of this virus via PK.33 Several cases of transplantation of corneas from HIV positive donors have been documented but none of these cornea recipients have seroconverted to an HIV positive status. $20,35,36$

Feline herpesvirus-1 is the only viral pathogen in the cat known to be directly responsible for corneal disease. 37,38 Studies have not been performed to evaluate for corneal tropism of any of the feline retroviruses. Given the incidence of retroviral 
infection in the domestic cat population, it is possible that transfer of infection via allograft transplantation could occur.

The feline leukemia virus (FeLV) is a retrovirus reported to infect approximately $2-3 \%$ of the cat population in the United States and is the leading viral cause of morbidity and mortality in this species. 39,40 In high risk populations and in multiple cat households where FeLV is enzootic, $13-30 \%$ of cats may be positive for FeLV antigens. ${ }^{41}$ Although the usual route of transmission of FeLV is oronasal contact with infectious saliva, infection via blood transfusion has also been documented. 39

Identification of FeLV infected cats relies on enzyme-linked immunosorbent assay (ELISA), indirect fluorescent antibody (IFA), and virus isolation (VI) techniques applied to blood, plasma, or serum. ${ }^{42-45}$ ELISA techniques have also been applied to tear and saliva samples, but with less accuracy.46, 47 Commerical ELISA test kits have given similar results when compared to each other. 48,49 ELISA detects soluble group-specific antigen p27 in body fluids, whereas the IFA technique is generally applied to whole blood and bone marrow smears to detect group-specific antigen associated with the cytoplasm of infected leukocytes. IFA technique has also been applied to other tissues for detection of infection. 50 Definitive detection of the presence of infectious virus requires VI. IFA and VI test results agree $97 \%$ to $99 \%$ of the time and because IFA is a much more practical and economical test to perform, VI is rarely performed in clinical situations. 39 , 51

Because false positive ELISA tests occur, it is recommended that ELISA positive cats be re-tested by IFA. $39,45,52$ In contrast, ELISA negative results are predictive of a true disease-free status greater than $99 \%$ of the time. 48 A study which evaluated 2000 blood samples by ELISA and VI revealed 100\% concordance for negative test results, whereas $10 \%$ of ELISA positive samples were VI negative. 51 It is not uncommon to find disagreement, or discordance, between ELISA and IFA tests. While ELISA/IFA and 
ELISA/VI discordance rates have been reported to range from $10 \%$ to greater than $50 \%$, most modern ELISA kits have a discordance rate closer to $10 \% .48,51,53$

The pathogenesis of infection with FeLV has been elucidated to a large degree since the discovery of the virus in 1964. Not all cats infected with FeLV become viremic. Approximately $30 \%$ of infected animals develop persistent viremia, with the remainder of cats either clearing the virus or developing sequestered or latent infection. ${ }^{39}$ Most IFA positive animals remain persistently viremic, with only $3 \%$ to $9 \%$ of IFA positive cats having a transient viremia. ${ }^{54}$ Persistent viremia allows dissemination of virus throughout the body, resulting in widespread replication of FeLV. FeLV replicates in many epithelial tissues, including the salivary glands, oropharynx, esophagus, stomach, intestine, trachea, nasopharynx, renal tubules, bladder, pancreas, alveolar ducts, and sebaceous ducts on the muzzle. 50,55 Infectious virus is shed into saliva, urine, and tears and can be consistently isolated from these secretions. $46,56,57$ In one report, ocular tissues were examined by IFA for presence of FeLV, but results were negative. 50 A wide range of disease states can result from FeLV infection, including myeloproliferative disorders, lymphoma, enteritis, infertility and abortion, glomerulonephritis, and neurologic disorders. ${ }^{58}$ In addition, immunosuppression occurs resulting in potential susceptibility to secondary pathogens.

Cellular infection begins with viral attachment to gp70 receptors on the target cell surface. 59 After cell membrane penetration, the viral outer coat is shed. Viral reverse transcriptase activity results in a complementary DNA (cDNA) copy of FeLV RNA. The cDNA strand serves as a template for second-strand DNA synthesis by the host's cellular DNA-dependant DNA polymerase, resulting in a double-stranded (ds) DNA copy. 60 The dsDNA circularizes and is then integrated into the cat cellular chromosomes. Integrated dsDNA is referred to as FeLV DNA provirus. 
Sequestered and latent FeLV infections are two poorly understood phases of the disease. These infections are non-viremic, although intermittent antigenemia may occur with sequestered infections. 61 Latent infections are thought to be harbored in bone marrow cells and a minor subset of nodal lymphocytes and can be reactivated by corticosteroid administration. ${ }^{62}$ Spontaneous reactivation has been documented but is thought to be a rare occurrence. 61 One experimental study detected localized FeLV antigen expression in tissues of 5 of 19 nonviremic cats. 63 The frequency of these types of infection in nature is uncertain. Factors such as initial virus burden, virus strain, and host immunity may determine whether an individual animal will effectively extinguish an infection or remain with latent or sequestered infection.

Ocular diseases attributed to FeLV include anterior uveitis, lymphoma, and pupillary motility disorders. ${ }^{64-67}$ Retinal hemorrhage secondary to severe FeLVassociated anemia has also been reported. 66 Some have suggested that FeLV causes no primary ocular disorder and that ophthalmic lesions noted in FeLV infected cats are only attributable to lymphoma and/or anemia. 66, 68 FeLV infection has not been directly linked to corneal disease in the cat. Yet because of the widespread presence of FeLV in epithelial tissues, it is reasonable to believe that virus may be present in corneal epithelium. Since productive infection by FeLV is generally not a cytopathic event, it is feasible that FeLV infection of corneal epithelium may occur without causing a clinical keratopathy. 39

FeLV is a fragile virus in the environment, being readily inactivated by desiccation, ultraviolet (UV) light, and heat. ${ }^{69,70}$ If kept moist in an appropriate media, including whole blood, serum or tissue culture media, the virus remains infective for 48 hours at $37^{\circ} \mathrm{C}$ and for nearly a week at room temperature. If frozen, the virus remains stable indefinitely. Corneal graft tissues are harvested and held in a biologic media and/or frozen, depending on the length of time which will lapse between harvesting and 
utilization. ${ }^{71}$ These storage conditions are suitable for maintenance of FeLV infectivity. If present in donor corneal tissues, FeLV could then be transmitted to a graft recipient.

First described in 1985, the polymerase chain reaction (PCR) is a technique which amplifies a known sequence of DNA to a level detectable with available methods, such as gel electrophoresis. ${ }^{72,} 73$ The procedure is cyclic with each cycle consisting of 3 steps: denaturation, annealing, and extension. The first step is denaturation of the DNA double helix and is generally carried out at temperatures of $94-98^{\circ} \mathrm{C}$. This step separates the template DNA strands and allows access by synthetic oligonucleotide primers to their complementary region of the ssDNA. During the second step of the cycle the reaction is cooled to a temperature of $37-60^{\circ} \mathrm{C}$ which allows primers to anneal to their target sequences of DNA. Extension is usually carried out at $72^{\circ} \mathrm{C}$ and during this step a DNA polymerase allows template-specific pairing of deoxynucleotide triphosphates (dNTPs) and propagation of the DNA strand of interest (target).

Following PCR, reaction products are separated by agarose gel electrophoresis. Ethidium bromide can be incorporated in the gel or applied in a subsequent staining step to bind DNA which is present. This DNA-ethidium bromide complex will fluoresence under UV illumination allowing visualization of PCR products. If a DNA marker of known base pair (bp) size is included on the gel, it can be visually ascertained whether amplification of a sequence the size of the intended target has occurred. This is presumptive evidence that the DNA sequence in question was present in the original sample. Because there is a possibility of mispriming and production of products of a similar length, yet dissimilar sequence, confirmation of the identity of the reaction product is required. A common technique for confirming the identity of a nucleotide sequence involves use of a nucleotide probe which if present will hybridize to the sequence of interest. A more definitive method for determining identity of the reaction product is to evaluate its nucleotide sequence and compare this to the intended target. If sufficient homology exists between target and product nucleotide sequence, this confirms that the intended sequence was amplified. 
A distinct advantage of the PCR technique over other diagnostic tests is sensitivity. A $10^{6}$ fold amplification of the target DNA sequence can be achieved following 30-35 reaction cycles. 73 This allows specific detection of minute amounts of DNA in biologic samples. This extreme sensitivity renders the technique susceptible to false positive results, especially if strict precautions to avoid cross-contamination are not employed during sample processing. The potential for errors in sample processing warrants extensive use of positive and negative controls when performing PCR.

PCR has been used to detect viral DNA in human corneal tissue including herpesviruses, HIV, and hepatitis B virus. $22,25-27,74,75$ In veterinary medicine, PCR has been used to detect several feline disease-causing agents including feline herpesvirus1, feline infectious peritonitis virus, panleukopenia virus, feline immunodeficiency virus, feline leukemia virus, Toxoplasma gondii, and Chlamydia psittaci.76-87 Feline herpesvirus-1 has recently been detected in feline corneal tissue by use of this technique. 77

The cellular DNA of healthy, uninfected cats contains nucleotide sequences related to and with partial homology to exogenous FeLV.88 These similarities complicate viral DNA detection by PCR if the region selected for amplification is one where homology exists between the two. Major dissimilarities between endogenous FeLV-related sequences and exogenous FeLV are reported to lie within the U3 region of the long terminal repeat (LTR) sequence.89, 90 The U3 region is highly conserved among exogenous FeLV isolates, with an overall sequence conservation of at least 95\% when multiple isolates from the United States and the United Kingdom were compared.90 These properties make the U3 region an appropriate target for the PCR reaction. Oligonucleotide primers targeting sequences of variable bp size within the U3 region have successfully identified FeLV proviral DNA in both peripheral blood and formalin-fixed tissue samples. $84-86$ 
Immunohistochemical (IHC) staining methods utilize specific antibodies to detect antigens of interest in tissue samples. The antibodies are labeled with a marker, which can be visualized by light microscopy. IFA techniques have been the mainstay of immunohistochemical detection systems for years, but several drawbacks exist with the use of this technique. Staining produced in tissues by IFA is labile and can only be visualized with a UV light microscope. Enzyme-labeled antibody techniques have an advantage over IFA by providing a means for signal amplification of the antigen-antibody reaction. ${ }^{91}$ In addition, tissue stains produced with enzyme-labeled techniques are permanent and can be viewed by conventional light microscopy.

Several immunoenzyme methods are currently employed in diagnostic pathology. 92 The simplest method is the direct immunostain where the antibody is directed against the antigen of interest and is conjugated with an enzyme, usually peroxidase. After antiserum is incubated with the tissue being tested, enzyme substrate is added resulting in deposition of an insoluble colored product at sites of antibody binding. Direct immunostaining techniques are simple to perform but provide little amplification of the visible signal compared to indirect and avidin-biotin complex (ABC) methods.

Indirect immunostaining methods utilize a primary antibody directed against the antigen of interest and a secondary enzyme-conjugated antibody which is directed against the primary antibody. Because several enzyme-conjugated antibodies can bind to each primary antibody, visible signals are intensified when enzyme substrate is added. Further signal amplification of the antigen-antibody reaction can be obtained by the $\mathrm{ABC}$ method.93 In this method, primary antibody directed against the antigen of interest is again used and a biotinylated secondary antibody is then employed. Following application of the secondary antibody, pre-formed avidin-biotin complexes are introduced to the tissue sample. Biotin molecules in these complexes are usually labeled with the enzyme peroxidase. When complexes are produced, free binding sites are left on the avidin so that they may bind to the biotinylated secondary antibody when introduced to 
the tissue. Since 4 biotin binding sites are available on each avidin molecule, substantial signal amplification is achieved with this method. Although the $\mathrm{ABC}$ method is more technically demanding than the direct or indirect immunostaining methods, the increased sensitivity of this technique makes it desirable when tissues have been antigenically altered by formalin fixation or when antigens are scarce in the tissue of interest. 92

Immunohistochemical techniques have been extensively employed in the study of FeLV. IFA is commonly utilized in the identification of infected animals where it is applied to whole blood or bone marrow smears. 44,94 It has also been applied to fixed tissues in studies elucidating the pathogenesis of this disease.50, 55 Recently, ABC immunoperoxidase techniques have been utilized to determine the presence of FeLV antigens in formalin fixed tissues. 84

The objectives of this study were to determine the presence of FeLV proviral DNA and antigens in the corneal tissues of FeLV infected cats. PCR and immunohistochemical staining methods were employed. PCR was utilized due to the sensitivity and specificity of this technique, while immunoperoxidase staining was employed to provide localization of virus to particular regions of the cornea (i.e. epithelium, stroma, or endothelium). 


\section{Method and Materials}

Thirty four random source cats of various ages and sexes were used in this study. Euthanasia of all cats was planned for reasons unrelated to completion of this project and collection of samples. Procedures and experimental design of this project were approved by the University Animal Care and Use Committee of VPI \& SU.

Cats were screened for the presence of free p27 antigen in peripheral blood by use of a commerical ELISA test kit. ${ }^{\mathrm{e}}$ Blood samples were obtained by jugular veinpuncture and placed in vacuum tubes containing EDTA anticoagulant. ${ }^{\mathrm{f}}$ Cats found to be positive on ELISA tests were assessed for persistent viremia by use of an IFA technique on peripheral blood smears for presence of FeLV gsa. ${ }^{\mathrm{g}}$

All cats had slit lamp biomicroscopy (SLB) performed to exclude existing corneal pathology. Only cats with normal SLB corneal examinations were included into this study. Euthanasia was induced by an intravenous barbiturate overdose. ${ }^{\mathrm{h}}$

\section{Corneal Samples}

Following euthanasia, a $9.0 \mathrm{~mm}$ central corneal button was harvested from each eye of each cat utilizing a corneal trephine and corneal transplant scissors. ${ }^{i}$ All corneal collections were performed by the primary investigator in the same controlled environment. Between collections, all instruments were thoroughly rinsed and then placed in an ultrasonic instrument cleaner. The left corneal tissue button was used for all tests and data analysis. The right corneal button sample was used for development of PCR and immunohistochemical staining techniques. Immediately upon removal of corneal buttons, each cornea was rinsed three times in a phosphate buffered saline solution (PBS) to remove residual tears and aqueous humor from tissue surfaces and was then sectioned into two equal portions. One half of each corneal button was placed in a $10 \%$ buffered formalin solution and the other half of corneal tissue was frozen in one milliliter of $\mathrm{PBS}$ at $-80^{\circ} \mathrm{C}$. Formalin-preserved corneal tissue was paraffin-embedded 
within 24-48 hours after collection. All corneal samples were stored for simultaneous analysis.

\section{Polymerase Chain Reaction}

Cultured FL74 cells, a persistently FeLV-infected cell line, served as a positive control for PCR reactions. FL74 cells were grown in EMEM media with 10\% fetal bovine serum and glutamine added. DNA extraction was performed on samples utilizing a commercial DNA extraction kit. ${ }^{j}$ Extraction procedures for cultured FL74 cells followed manufacturer's recommended protocol for cultured cells. DNA was extracted from corneal tissue samples following the manufacturer's "Mouse Tail Protocol".

Oligonucleotide primers targeting a 495 base pair (bp) sequence within the FeLV U3 LTR region were designed ${ }^{\mathrm{k}}$ and synthesized. ${ }^{1}$ Forward and reverse primers were, respectively: GCCAGCTACTGCAGTGGTGTCAT (forward) and CTGGGGGTTGGGGGTCTTTATCC (reverse). The U3 region was considered an appropriate target for PCR reactions.

Ready-to-go PCR beads ${ }^{\mathrm{m}}$ were used for the PCR reaction following manufacturer's recommended protocol. A $1 \mu \mathrm{l}$ sample volume of DNA template and 10 nmol of both forward and reverse primers were added to each reaction. Reaction volume was brought to a final volume of $25 \mu \mathrm{l}$ with HPLC grade water and overlaid with $25 \mu \mathrm{l}$ sterile mineral oil. A positive DNA control sample was provided by DNA extracted from FL74 cells. A blank reaction consisting of primers but no DNA template was included in each run to serve a reagent control. Reaction was carried out in a DNA thermal cycler. An initial denaturation step was performed at $95^{\circ} \mathrm{C}$ for 4 minutes. Each PCR cycle included denaturation at $95^{\circ} \mathrm{C}$ for one minute, primer annealing at $58^{\circ} \mathrm{C}$ for 1 minute and extension at $72^{\circ} \mathrm{C}$ for 1 minute. Thirty-five cycles were performed on each sample. Samples were held at $4^{\circ} \mathrm{C}$ until further analysis. 
Seven $\mu \mathrm{l}$ of PCR product was mixed with $3 \mu \mathrm{l}$ of loading dye. ${ }^{\circ}$ The $10 \mu \mathrm{l}$ mixture was loaded onto a $1 \%$ agarose gel with ethidium bromide added. A 1 kb DNA ladder was included on each gel. ${ }^{\circ}$ Electrophoresis in 0.5X Tri-Borate-EDTA (TBE) buffer was performed at constant voltage, 85 volts, for approximately 150 minutes. ${ }^{\mathrm{p}}$ Following electophoresis the gel was photographed under UV transillumination. ${ }^{\mathrm{q}}$

\section{Cloning of PCR Product}

Four randomly selected PCR positive samples were cloned for subsequent DNA sequencing using a commercial cloning kit. ${ }^{\mathrm{r}}$ A $2 \mu \mathrm{l}$ sample of each PCR product to be cloned was inserted into a plasmid vector following the manufacturer's recommended protocol. The reaction was transformed into chemically competent E. coli cells $\left(\mathrm{DH} 5 \alpha^{\mathrm{TM}}\right)$ following the supplier's protocol. LB plates with $50 \mu \mathrm{g} / \mathrm{ml}$ Ampicillin were coated with $100 \mu \mathrm{l} 2 \% \mathrm{X}$-gal and $100 \mu \mathrm{l}$ isopopyl-B-D-thiogalacto-pyranoside (IPTG) and allowed to dry. Following a 1 hour incubation period at $37^{\circ} \mathrm{C}$ in a shaker bath, transformed E. coli cells (DH5 $\alpha^{\mathrm{TM}}$ ) were plated onto the coated LB plates. Plates were incubated overnight at $37^{\circ} \mathrm{C}$. To screen for plasmid inserts, a rapid screening protocol was employed ${ }^{\mathrm{s}}$

\section{$\underline{\text { Rapid Screening Protocol }}$}

From each culture plate, six white colonies were selected to screen for inserts. Two dark blue colonies containing only plasmid vector were chosen as controls. A sample of each chosen colony was incubated in $1 \mathrm{ml}$ Terrific Broth-Ampicillin (TB-Amp) media in a $1.6 \mathrm{ml}$ microcentrifuge tube and also streaked on a TB-Amp master plate. Both were incubated overnight at $37^{\circ} \mathrm{C}$. Following incubation, liquid cultures were centrifuged at 10,000 rpm for 2 minutes. Supernatant was discarded and $5 \mu$ RNAase was added to each tube. The cells were resuspended by vortexing and then allowed to incubate for 15 minutes. $50 \mu \mathrm{l}$ phenol-chloroform was added to each tube and each sample was then vortexed for 1 minute. Samples were centrifuged at 15,000 rpm for 1 minute, and $10 \mu \mathrm{l}$ of the supernatant was loaded onto a $1 \%$ agarose gel with ethidium bromide. Electrophoresis was performed at 100 volts for 1 hour and visualized under UV 
transillumination. An approximately 500bp upward shift on the gel, when compared to the plasmid control, was interpreted to represent successful ligation of an insert. After determining which samples contained inserts, the growth on the corresponding master plate was cultured in $10 \mathrm{ml}$ trypticase soy broth $(\mathrm{TSB})^{\mathrm{t}}$ with $10 \mu \mathrm{l}$ Ampicillin $(200 \mu \mathrm{g} / \mathrm{ml})$ added and incubated overnight at $37^{\circ} \mathrm{C}$. Three milliliters from each culture tube was purified utilizing a commercial column per the manufacturer's recommended protocol. ${ }^{u}$ To verify that the correct PCR product had been inserted into the vector, restriction analysis was performed by digestion with EcoRI and $10 \mu \mathrm{l}$ of the product of this reaction was electrophoresed on a $1 \%$ agarose gel with ethidium bromide followed by visualization under UV transillumination.

\section{DNA Sequencing and Analysis}

DNA was purified for sequencing using a commercial DNA preparation kit following the manufacturers recommended protocol ${ }^{\mathrm{v}}$ and the product was resuspended in $35 \mu \mathrm{l}$ sterile water. The purified DNA product was sequenced in both directions by a semi-automated fluorescent DNA sequencer ${ }^{\mathrm{w}}$ using the Cycle Sequencing Protocol. Sequence analysis was performed. ${ }^{\mathrm{k}}$

\section{Immunohistochemistry}

Corneal tissues were immediately placed in $10 \%$ buffered formalin solution and paraffin-embedded within 48 hours of tissue collection. Paraffinized corneal tissues were sectioned at six $\mu \mathrm{m}$ for immunohistochemical analysis. The avidin-biotin complex $(\mathrm{ABC})$ technique was performed on corneal sections from each subject essentially as

previously described. 84 The primary antibody used was goat anti-FeLV gp $70^{\mathrm{x}}$ and secondary antiserum was biotinylated mouse anti-goat $\mathrm{IgG}^{\mathrm{y}}$ Primary antibody was applied to the corneal sections at a dilution of 1:4000 and the secondary antiserum was applied at a dilution of 1:20 and 1:50. A commercial ABC peroxidase detection system ${ }^{\mathrm{Z}}$ developed with the chromagen di-amino-benzidine was utilized and sections were counterstained with hematoxylin. Sections of each tissue were tested with an irrelevant goat serum (no anti-FeLV activity) substituted for the anti-FeLV antiserum. 
Up to four sections from each cornea were stained and evaluated. Sections were reviewed for specific staining and graded as positive or negative by two blinded observers. Positive specific staining was coarse granular staining, most prominent on the surfaces of corneal epithelial cells.

\section{Statistical Analysis}

Agreement between tests for ELISA and PCR, ELISA and IHC, IFA and PCR, IFA and IHC, and PCR and IHC were calculated by use of a kappa statistic that identifies the probability of agreement between two non-parametric tests.95 A scale for interpretation of kappa values is included as Appendix A.

* Unless otherwise stated, all molecular biology reagents were obtained through Fisher Scientific, Fairlawn, NJ. 


\section{Results}

Corneal tissues from the left eye were obtained and analyzed from 34 random source cats. FeLV ELISA testing revealed 17 positive and 17 negative cats. Twelve of 17 ELISA positive cats (70.6\%) were also positive on the IFA test on peripheral blood smears. Three ELISA positive cats were negative on peripheral blood IFA testing with two cats having indeterminate IFA test results (Table 1).

PCR test results were considered positive if a 495 bp band was visualized on ethidium bromide-agarose gel electrophoresis viewed with UV transillumination. DNA extracted from FL74 cells was consistently positive on PCR testing, and reagent controls were consistently negative. (Figure 1 and 2).

Eleven (64.7\%) of 17 ELISA positive cats were positive on corneal PCR. All positive corneal PCR results were from ELISA positive cats. Six (35.3\%) of the corneas

from ELISA positive cats were PCR negative. Twelve cats were ELISA and IFA positive on peripheral blood samples and, of these, 10 (83.3\%) cats had positive corneal PCR results. One corneal PCR positive cat had an indeterminate peripheral IFA result. Two ELISA and IFA positive subjects had negative corneal PCR results. All corneal tissues from ELISA negative cats were found to be PCR negative.

DNA sequencing was performed on four randomly selected PCR positive corneal products. After cloning of the PCR product and purification of the DNA, two of the samples were sequenced forward and two products were sequenced in reverse. Lengths of the forward sequences were $334 \mathrm{bp}$ and $348 \mathrm{bp}$, while $421 \mathrm{bp}$ and $362 \mathrm{bp}$ extensions were obtained on the reverse sequenced samples. Approximately $200 \mathrm{bp}$ regions of overlap were obtained in sequence which allowed a consensus sequence to be constructed (Figure 3). Comparison of the consensus sequence with a previously published FeLVA/Glasgow (Glas1) sequence revealed 93\% homology between the two. 
IHC staining of corneal sections revealed the presence of FeLV gp70 in corneal tissues of nine (52.9\%) ELISA positive cats. Corneal tissues of eight (47.1\%) ELISA positive cats were negative on IHC testing. Of the 12 cats which were both ELISA and IFA positive on peripheral blood, $8(66.7 \%)$ had positive corneal IHC results. One corneal IHC positive cat had an indeterminate peripheral IFA result. Corneal tissues of all three ELISA positive, IFA negative cats were negative on IHC testing. One cornea was PCR negative and IHC positive. All corneal tissues from ELISA negative cats were negative on IHC testing.

Specific IHC staining was localized to the corneal epithelium. Positive specific staining was coarse granular staining which was most prominent on the surfaces of corneal epithelial cells (Figure 3 and 4). No specific staining was noted in the corneal stroma, Descemet's membrane, or corneal endothelium. No specific staining was noted on corneal sections from ELISA negative cats (Figures 5 and 6), nor was staining detected when irrelevant goat serum was used in place of goat anti-FeLV antiserum.

A kappa statistic was calculated to determine the strength of agreement between tests for ELISA and PCR ( $\mathrm{k}=0.65)$, ELISA and IHC ( $\mathrm{k}=0.53)$, IFA and PCR $(\mathrm{k}=0.67)$, IFA and IHC ( $\mathrm{k}=0.44)$, and IHC and PCR $(\mathrm{k}=0.52)$. Moderate to substantial agreement was found between all tests compared (Table 2). 


\section{Discussion}

Results of this study show that FeLV proviral DNA and FeLV antigens are present within the corneal epithelium of some FeLV infected cats. Immunohistochemical staining showed FeLV gp70 antigens to be localized to the anterior corneal epithelium. Although FeLV has previously been detected in many epithelial tissues of infected cats, this is the first confirmation of corneal epithelial infection.

The majority of ELISA positive cats studied were also positive on peripheral blood IFA testing and were considered to be persistently infected with FeLV. IFA test results correlate well with VI studies, while VI attempts may be negative in some cats with a positive ELISA test. 51 Persistent FeLV viremia in cats results from ineffective host immune responses that allows dissemination to, and replication in, many epithelial tissues. Previous investigators have attempted detection of FeLV in ocular tissues by use of IFA techniques, but documentation as to their success is lacking in the literature. 50

Feline herpesvirus- 1 is the only other viral agent that has been detected in the cornea of cats and is responsible for several corneal diseases in this species. Although cats in this study did not have evidence of corneal disease based on slit lamp biomicroscopy, the presence of FeLV proviral DNA and FeLV antigens in corneal tissues warrants caution in use of random source cats as corneal donors without prior FeLV testing. Because of these findings, further study of this viral agent and it's potential role in corneal disease is also indicated.

Cats with discordant tests, i.e. a positive peripheral blood ELISA and negative blood IFA, represented a minority of test subjects and were considered for the purposes of this study to have a transient viremia. False positive ELISA results, false negative IFA results due to technician error or low peripheral leukocyte counts, and antigenemia without cell-associated viremia (atypical infection) are possible explanations for discordant findings. Approximately $10-30 \%$ of cats tested with ELISA and IFA tests may 
have discordant results with one-half of these animals eventually converting to a seronegative status. $51-53$ The number of cats in our study with discordant results was approximately $30 \%$. Because we did not have an opportunity to retest cats with a positive ELISA and negative IFA, as would be the normal procedure in practice, we cannot definitively ascertain the cause of discordant results in these subjects. Cats testing positive on peripheral blood ELISA and indeterminate on IFA represented an additional $12 \%$ of the population. Retesting of these cats would be an important issue to ascertain the evolving status of infection but was not feasible to perform in this study. Early infection with FeLV, faulty technique, low number of white blood cell on peripheral blood sample and subjectivity in reading IFA by technical personnel are possible explanations for this result. Comparison of corneal findings in transient, persistent, sequestered and latent FeLV infection was not an objective of this study but is necessary for evaluating these test results and for providing optimal recommendations about use of corneal tissue for transplantation procedures.

PCR detected FeLV proviral DNA in 11/17 (64.7\%) of corneal samples in ELISA positive cats and in 10/12 (83.3\%) of cats with positive ELISA and IFA results. These results indicate that cats with persistent viremia, as determined by positive peripheral IFA results, were more likely to have a positive corneal PCR test. Circulating virus should be present in this group of cats and would be expected to localize and replicate in epithelial tissue resulting in a positive PCR test. It may be that FeLV subtype, stage or duration of infection and host-immune interactions played a role in ELISA positive cats that did not have a positive PCR result on corneal tissues.

In addition to the corneal tissue itself, possible sources of proviral DNA which may have been amplified included infected cellular debris in residual tears and aqueous humor on the samples. Although the tissues were rinsed with buffered saline during processing to minimize this possible effect, it is possible that surface contamination remained. However, if these fluids affected PCR results by contaminating corneal samples, then more positive PCR test results might have been expected. Contamination 
with viral particles alone would not have resulted in positive PCR results because FeLV is an RNA virus which would not be amplified by routine PCR. Control cats and reagent controls were consistently negative on corneal PCR, which indicates that cross contamination did not occur during PCR processing of samples and is not accountable for positive PCR test results.

IHC testing detected viral antigen in corneal tissues of 9/17 (52.9\%) of ELISA positive cats and 8/12 (66.7\%) of cats that were ELISA and IFA positive. It is not surprising that these numbers are somewhat lower than those obtained by PCR. A likely explanation for this difference is the increased ability of PCR to detect low levels of virus as compared to IHC. Also, as previously mentioned, viral particles from aqueous humor or tears may have remained on the surface of the corneal tissue and been amplified by the PCR reaction. In this scenario, the particles may have been at levels sufficient for PCR amplification, but either below the detection limit of IHC testing or washed away during tissue processing. Alteration of gp70 antigens by formalin fixation may also have decreased the detection sensitivity of IHC. ${ }^{92}$ On IHC positive samples, positive staining was found scattered throughout the corneal epithelium in multiple discreet foci with IHC negative epithelium between. Because of this, it is possible that positive staining was missed on some samples even though multiple sections of each cornea were reviewed. As the reagent controls and ELISA negative cornea samples were routinely negative on PCR testing, it is unlikely that cross contamination during PCR processing accounts for the higher detection rates with PCR.

It is of interest that no ELISA negative cats studied were positive on PCR or IHC tests. Random source cats might be expected to have a higher incidence of sequestered or latent infection with FeLV that might lead to negative ELISAs and positive PCR tests. Over 50\% of cats infected with FeLV may develop a short-lived latent infection, harbored in bone marrow cells and a minor subset of nodal lymphocytes. Over time, the prevalence of latent infection is thought to diminish with only $10 \%$ of cats with virus neutralizing antibodies having latent infection after 3 years. 96,97 In latent infections, 
virus is maintained integrated within host cellular DNA in a non-replicating state with little or no consequence to the host unless virus reactivation occurs. Five to $10 \%$ of cats exposed to FeLV may develop a sequestered infection where the virus is maintained in various tissues and may exhibit intermittent antigenemia without detectable viremia. 53 , 61, 63 Perhaps testing a higher number of ELISA negative cats by corneal PCR would identify such individuals.

Several cats had less agreement between peripheral blood tests and tests conducted on corneal tissues. Three cats in this study were ELISA positive and IFA negative (discordant). This percentage of discordant test results is similar to previous reports. Corneal tissues from these subjects were negative on both PCR and IHC testing. These subjects may have been harboring FeLV infection in a non-myeloid compartment or, alternatively, these may have been false positive ELISA test results. In either case, negative corneal test results are expected. Two subjects were ELISA positive with indeterminate IFA test results. Of these, one cat was negative on both PCR and IHC corneal testing and one was positive on both. Comparison with results from other cats studied makes it likely that these cats were true FeLV negative and positive animals, respectively. One cat was noted to have a negative PCR and a positive IHC corneal sample. This cat was positive for FeLV on both ELISA and IFA testing from a peripheral blood sample. The presence of FeLV antigen in the corneal sample, as detected by IHC testing, suggests that virus was present within the corneal tissue and therefore should have been detected by PCR testing. On retesting, the sample was repeatedly PCR negative. The most likely explanations for this discrepancy are chemical or physical interference with the PCR reaction for that sample or an inadequate DNA template due to degradation by DNAase activity or some other means. A similar finding was encountered in a study comparing PCR and IHC results for FeLV on lymphosarcoma tissues. 84

Determination of the level of agreement between the tests performed in positive and negative cats revealed a range of kappa values from $0.44-0.67$. This range indicates moderate to substantial agreement for all tests evaluated. The highest level of 
agreements , based on kappa values, was present between peripheral blood tests (ELISA and IFA) and PCR test on corneal tissue. The more moderate level of agreement found between peripheral blood tests (ELISA and IFA) and IHC is likely the result of a lower degree of sensitivity of IHC as compared to PCR.

At this time, FeLV infection is not reported as a primary cause of keratopathy in the cat and the clinical implication of our findings lies in recommendation for use of corneal tissue for transplantation. Because FeLV proviral DNA and FeLV antigens were detected within corneal tissues, a potential for iatrogenic transmission of infection via PK does exist. Viral infectivity is maintained under storage conditions for transplant tissue. Infectious virions shed into the tear film from the transplanted corneal tissue and inoculation by neovascular ingrowth are both potential routes of infection via PK. If infected corneal tissue were transplanted, factors such as pre-existing recipient corneal neovascularization, viral load in the donor corneal epithelium, and previous exposure status of the recipient might influence the outcome regarding transmission of infection.

PK is not performed frequently in the cat but indications for the procedure do exist and success rates for this procedure in this species are reported to be high. 16,17 Because of the potential consequences of iatrogenic FeLV transmission, it is our recommendation that appropriate screening of corneal donors be performed. While ELISA positive animals had variable corneal PCR and IHC test results in this study, ELISA negative cats were consistently negative on PCR and IHC tests. This finding, in addition to previous documentation of the reliability of negative ELISA tests, suggests that a negative ELISA test is sufficient for excluding or decreasing the likelihood of iatrogenic FeLV transmission by PK. The presence of other feline retroviruses such as FIV in corneal tissues has not been reported, but testing donors for this virus would also be advisable. 


\section{Footnotes}

a. Glaze MB, Personal communication, 1995

b. Berger SL, Personal communication, 1996

c. Peiffer RL, Personal communication, 1996

d. Glover TL, Personal communication, 1997

e. ViraCHECK®, Synbiotics Corp., San Diego, CA

f. Becton Dickinson VACUTAINER Systems, Franklin Lakes, NJ

g. VMRD, Inc., Pullman, WA

h. Beuthanasia-D Special ${ }^{\circledR}$, Shering-Plough Animal Health Corp., Kenilworth, NJ

i. Storz, St. Louis, MO

j. QIAGEN, Inc., Santa Clarita, CA

k. Lasergene, DNASTAR, Inc., Madison, WI

1. Genosys Biotechnologies, Inc., The Woodlands, TX

m. Pharmacia Biotech, Piscataway, NJ

n. Omnigene Thermal Cycler, Hybaid

o. Promega, Madison, WI

p. Model 3000/300 power supply, BioRad, Hercules, CA

q. Fotodyne UV Translilliminator, Fotodyne, Inc., Hartland, WI

r. TOPO TA Cloning ${ }^{\circledR}$ Kit, Invitrogen, Carlsbad, CA

s. John McQuiston, Personal communication, 1998

t. Difco Laboratories, Inc., Detroit, MI

u. QIAprep Spin, QIAGEN, Inc., Santa Clarita, CA

v. Qiatip-20, QIAGEN, Inc., Santa Clarita, CA

w. ALFExpress, Pharmacia Biotech, Piscataway, NJ

x. National Cancer Institute, Bethesda, MD

y. Sigma Chemical Co., St. Louis, MO

z. Vectastain Elite ABC, Vector Laboratories, Burlingame, CA 


\section{References}

1. de Quengsy P. Precis au cours d'operations sur la chirurgue des yeux. Paris: Didot, 1789.

2. Darwin E. Zoonomia; or The Laws of Organic Life. , Vol II. London, 1796; 48.

3. Reisinger F. Die keratoplastik ein Versuch zur Erweiterung der Angenheilkunst. Bayerische Annalen 1824; 1: 207-215.

4. Bigger S. Inquiring into the possibility of transplanting the cornea, with the view of relieving blindness (hitherto deemed incurable) caused by several diseases of that structure. Dublin J Med Sci 1837; 11: 408-417.

5. Kissam RS. NY J Med 1844; 2: 281.

6. Power H. IV International Congress of Ophthalmology, London, 1872.

7. von Hippel A. Albrecht v Graefes Arch Ophthalmol 1888; 34: 108.

8. Zirm E. Eine erfolgreiche totale keratoplastik. Graefe's Arch Clin Exp Ophthalmol 1906; 64: 580-593.

9. Brightbill FS, Brass RE. Preoperative evaluation of the keratoplasty patient. In: Krachmer JH, Mannis MJ, Holland EJ, eds. Cornea: Surgery of the Cornea and Conjunctiva., Vol III. St. Louis: Mosby-Year Book, 1997; 1563.

10. Jensen EC. Experimental corneal transplantation in the dog. J Am Vet Med Assoc 1963; 142(1): 11-23.

11. Dice PF, Severin GA, Lumb WV. Experimental autogenous and homologous corneal transplanation in the dog. J Am Anim Hosp Assoc 1973; 9: 245-251.

12. Keller WF, Blanchard GL, Kuhns EL. The clinical application of homologous corneal and scleral grafts in the dog. J Am Anim Hosp Assoc 1973; 9: 265-269.

13. Gwin RM, Polack FM, Warren JK, et al. Primary canine corneal endothelial cell dystrophy: Specular microscopic evaluation, diagnosis and therapy. J Am Anim Hosp Assoc 1982; 18: 471-479.

14. Hacker DV. Frozen corneal grafts in dogs and cats: a report on 19 cases. $J$ Am Anim Hosp Assoc 1991; 27: 387-398. 
15. Whittaker CJG, Smith PJ, Brooks DE, et al. Therapeutic penetrating keratoplasty for deep corneal stromal abscesses in eight horses. Vet \& Comp Ophthalmol 1997; 7(1): 19-28.

16. Bahn CF, Meyer RF, MacCallum DK, et al. Penetrating keratoplasty in the cat: A clinically applicable model. Ophthalmol 1982; 89(6): 687-699.

17. Bahn CF, MacCallum DK, Lovett EJ, et al. Corneal transplantation in the cat: Cellular immune mechanisms in graft survival and rejection. Cornea 1983; 2(4): 263275.

18. Antonios SR, Cameron JA, Badr IA, et al. Contamination of donor cornea: Postpenetrating keratoplasty endophthalmitis. Cornea 1991; 10(3): 217-220.

19. Gottesdiener KM. Transplanted infections: Donor-to-host transmission with the allograft. Ann Intern Med 1989; 110(12): 1001-1016.

20. Pepose JS. Transfer of infection via corneal transplantation. Transplant Proc 1989; 21(1): 3130-3132.

21. Zaidman GW, Billingsley A. Corneal impression test for the diagnosis of acute rabies encephalitis. Ophthalmol 1998; 105(2): 249-251.

22. Garcia-Ferrer FJ, Laycock KA, Buerger DG, et al. Screening corneas for human immunodeficiency virus type 1 proviral DNA by polymerase chain reaction. Am J Ophthalmol 1995; 119(1): 7-13.

23. Raber IM, Friedman HM. Hepatitis B surface antigen in corneal donors. Am J Ophthalmol 1987; 104: 255-258.

24. Khalil A, Ayoub M, Abdel-Wahab KSED, et al. Assessment of the infectivity of corneal buttons taken from hepatitis B surface antigen seropositive donors. $\mathrm{Br} \mathrm{J}$ Ophthalmol 1995; 79: 6-9.

25. Shimazaki J, Tsubota K, Sawa M, et al. Detection of human immunodeficiency virus, hepatitis B virus, and hepatitis $\mathrm{C}$ virus in donor eyes using polymerase chain reaction. Br J Ophthalmol 1994; 78(11): 859-862.

26. Crouse CA, Pflugfelder SC, Periera I, et al. Detection of herpes viral genomes in normal and diseased corneal epithelium. Curr Eye Res 1990; 9(6): 569-581. 
27. Cantin EM, Chen J, McNeill J, et al. Detection of herpes simplex virus DNA sequences in corneal transplant recipients by polymerase chain reaction assays. Curr Eye Res 1991; 10 Supplement: 15-21.

28. Wehrly SR, Manning FJ, Proia AD, et al. Cytomegalovirus keratitis after penetrating keratoplasty. Cornea 1995; 14(6): 628-633.

29. Wilhelmus KR, Font RL, Lehman RP, et al. Cytomegalovirus keratitis in acquired immunodeficiency syndrome. Arch Ophthalmol 1996; 114: 869-872.

30. Power WJ, Hogan RN, Hu S, et al. Primary varicella-zoster keratitis: Diagnosis by polymerase chain reaction. Am J Ophthalmol 1997; 123(2): 252-254.

31. Van Rij G, Klepper L, Peperkamp E, et al. Immune electron microscopy and a cultural test in the diagnosis of adenovirus ocular infection. Br J Ophthalmol 1982; 66: 317-319.

32. Huoff SA, Burton RC, Wilson RW, et al. Human-to-human transmission of rabies virus by corneal transplant. N Engl J Med 1979; 300: 603-604.

33. O'Day DM. Diseases potentially transmitted through corneal transplantation. Ophthalmol 1989; 96(8): 1133-1137.

34. Duffy P, Wolf J, Collins G, et al. Possible person-to-person transmission of Creutzfeldt-Jakob disease. N Engl J Med 1974; 290: 692-693.

35. Schwarz A, Hoffman F, L'age-Stehr J, et al. Human immunodeficiency virus transmission by organ donation: outcome in cornea and kidney recipients. Transplantation 1987; 44(1): 21-24.

36. Simonds RJ, Holmberg SD, Hurwitz RL, et al. Transmission of human immunodeficiency virus type I from a seronegative organ and tissue donor. N Engl J Med 1992; 326(11): 726-732.

37. Bistner SI, Carlson JH, Shively JN, et al. Ocular manifestations of feline herpesvirus infection. J Am Vet Med Assoc 1971; 159: 1223-1237.

38. Nasisse MP, Guy JS, Davidson MG, et al. Experimental ocular herpesvirus infection in the cat: Sites of virus replication, clinical features, and effects of corticosteroid administration. Invest Ophthalmol Vis Sci 1989; 30: 1758-1768. 
39. Hardy WD. The feline leukemia virus. J Am Anim Hosp Assoc 1981; 17: 951980.

40. Barr MC, Olsen CW, Scott FW Feline viral diseases. In: Ettinger SJ, ed. Veterinary Internal Medicine, 4th ed. Philadelphia: WB Saunders, 1994; 409-439.

41. O'Connor TPJ, Tonelli QJ, Scarlett JM. Report of the national FeLV/FIV awareness project. J Am Vet Med Assoc 1991; 199110(1348-1353).

42. Mia AS, Kahn DE, Tierney MM, et al. A microenzyme-linked immunosorbent assay (ELISA) test for detection of feline leukemia virus in cats. Comp Immunol Microbiol Infect Dis 1981; 4: 111-117.

43. Lutz H, Pederson NC, Theilen GH. Course of feline leukemia virus infection and its detection by enzyme-linked immunosorbent assay and monoclonal antibodies. Am $J$ Vet Res 1983; 44: 2054-2059.

44. Hardy WDJ, Hirshaut Y, Hess P. Detection of the feline leukemia virus and other mammalian oncornaviruses by immunofluorescence. In: Dutcher RM, ChiecoBianchi L, eds. Unifying Concepts of Leukemia. New York: Karger and Basel, 1973; 778799.

45. Panel report on the colloquium on feline leukemia virus/feline immunodeficiency virus: Tests and vaccination. J Am Vet Med Assoc 1991; 199(10): 1273-1277.

46. Hawkins EC, Johnson K, Pederson NC, et al. Use of tears for diagnosis of feline leukemia virus infection. J Am Vet Med Assoc 1986; 188: 1031-1034.

47. Lewis MG, Wright KA, Lafrado LJ, et al. Saliva as a source of feline leukemia virus antigen for diagnosis of disease. J Clin Microbiol 1987; 25(7): 1320-1322.

48. Lopez NA, Jacobson RH, Scarlett JM, et al. Sensitivity and specificity of blood tests for feline leukemia virus antigen. J Am Vet Med Assoc 1989; 195(6): 747-751.

49. Hawks DM, Legendre AM, Rohrbach BW. Comparison of four test kits for feline leukemia virus antigen. J Am Vet Med Assoc 1991; 199(10): 1373-1376.

50. Rojko JL, Hoover EA, Mathes LE, et al. Detection of feline leukemia virus in tissues of cats by a parrafin embedding immunofluorescence procedure. J Natl Cancer Inst 1978; 61(5): 1315-1321. 
51. Jarret O, Golder MC, Weijer K. A comparison of three methods of feline leukaemia virus diagnosis. Vet Rec 1982; 110: 325-328.

52. Hardy WD, Zuckerman EE. Ten year study comparing enzyme-linked immunosorbent assays with the immunofluorescent antibody test for the detection of feline leukemia virus infection in cats. J Am Vet Med Assoc 1991; 199: 1365-1373.

53. Jarret O, Pacitti AM, Hosie MJ, et al. Comparison of diagnostic methods for feline leukemia virus and feline immunodeficiency virus. J Am Vet Med Assoc 1991; 199(10): 1362-1364.

54. Rojko JL, Hardy WD. Feline leukemia and other retroviruses. In: Sherding RG, ed. The Cat: Diseases and clinical management, 2nd ed: Churchill Livingstone, $1994 ; 263-432$.

55. Rojko JL, Hoover EA, Mathes LE. Pathogenesis of experimental feline leukemia virus infection. J Natl Cancer Inst 1979; 63: 759-768.

56. Francis DP, Essex M, Hardy WDJ. Excretion of feline leukemia virus by naturally infected pet cats. Nature 1977; 269: 252-254.

57. Hinshaw VS, Blank HF. Isolation of feline leukemia virus from clinical specimens. Am J Vet Res 1977; 38: 55-57.

58. Hoover EA, Mullins JI. Feline leukemia virus infection and diseases. J Am Vet Med Assoc 1991; 199(10): 1287-1297.

59. Laird HM, Jarrett O, Whalley JM. Electron microscopy of early interactions between feline leukaemia virus and cells in tissue culture. Bibl Haematol 1973; 39: 133 138.

60. Temin HM. Mechanism of cell transformation by RNA tumor viruses. Ann Rev Microbiol 1971; 25: 609-648.

61. Pacitti AM, Jarret O, Hay D. Transmission of feline leukemia virus in the milk of a non-viraemic cat. Vet Rec 1986; 118: 381-384.

62. Rojko JL, Hoover EA, Quackenbush SL, et al. Reactivation of latent feline leukemia virus infection. Nature 1982; 298: 385-388.

63. Hayes KA, Rojko JL, Mathes LE. Incidence of localized feline leukemia virus infection in cats. Am J Vet Res 1992; 53(4): 604-607. 
64. Gelatt KN, Whitley RD, Samuelson DA, et al. Ocular manifestations of viral diseases in small animals. The Compendium on Continuing Education for the Practicing Veterinarian 1985; 7(12): 968-977.

65. Brightman AH, Macy DW, Gosselins. Pupillary abnormalities associated with the feline leukemia complex. Feline Pract 1977; 5: 23.

66. Brightman AH, Ogilvie GK, Tompkins M. Ocular disease in FeLV positive cats: 11 cases (1981-1986). J Am Vet Med Assoc 1991; 198(6): 1049-1051.

67. Peiffer RLJ, Wilcock BP. Histopathologic study of uveitis in cats: 139 cases (1978-1988). J Am Vet Med Assoc 1991; 198: 135-138.

68. Nasisse MP. Feline ophthalmology. In: Gelatt KN, ed. Veterinary Ophthalmology, 2nd ed. Philadelphia: Lea \& Febiger, 1991; 529-575.

69. Heding LD, Schaller JP, Blakeslee JR, et al. Inactivation of tumor cellassociated feline oncornavirus for preparation of an infectious virus-free tumor cell immunogen. Cancer Res 1976; 36: 1647-1652.

70. Francis DP, Essex M, Gayzagdian D. Feline leukemia virus: Survival under home and laboratory conditions. J Clin Microbiol 1979; 9: 154-156.

71. Wilson SE, Bourne WM. Corneal preservation. Surv Ophthalmol 1989; 33(4): 237-259.

72. Saiki RK, Scharf S, Faloona F, et al. Enzymatic amplification of B-globin genomic sequences and restriction site analysis for diagnosis of sickle cell anemia. Science 1985; 230: 1350-1354.

73. Mullis KB, Faloona FA. Specific synthesis of DNA in vitro via a polymerasecatalyzed chain reaction. Methods Enzymol 1987; 155: 335-350.

74. Openshaw H, McNeill JI, Lin XH, et al. Herpes simplex virus DNA in normal corneas: Persistence without viral shedding from ganglia. J Med Virol 1995; 46(1): 75-80.

75. Mietz H, Eis-Hubinger AM, Sundmacher R, et al. Detection of varicella-zoster virus DNA in keratectomy specimens by use of the polymerase chain reaction. Arch Ophthalmol 1997; 115(5): 590-594. 
76. Reubel GH, Ramos RA, Hickman MA, et al. Detection of active and latent feline herpesvirus-1 infections using the polymerase chain reaction. Arch Virol 1993; 132(3-4): 409-420.

77. Stiles J, McDermott M, Bigsby D, et al. Use of nested polymerase chain reaction to identify feline herpesvirus in ocular tissue from clinically normal cats and cats with corneal sequestra or conjunctivitis. Am J Vet Res 1997; 58(4): 338-342.

78. Stiles J, McDermott M, Willis M, et al. Comparison of nested polymerase chain reaction, virus isolation, and fluorescent antibody testing for identifying feline herpesvirus in cats with conjunctivitis. Am J Vet Res 1997; 58(8): 804-807.

79. Weigler BJ, Babineau CA, Sherry B, et al. High sensitivity polymerase chain reaction assay for active and latent feline herpesvirus-1 infections in domestic dats. Vet Rec 1997; 140(13): 335-338.

80. Stiles J, Prade R, Greene C. Detection of Toxoplasma gondii in feline and canine biological samples by use of the polymerase chain reaction. Am J Vet Res 1996; 57(3): 264-267.

81. Schunk B, Kraft W, Truyen U. A simple touch-down polymerase chain reaction for the detection of canine parvovirus and feline panleukopenia virus in feces. $J$ Virol Methods 1995; 55(3): 427-433.

82. Gamble DA, Lobbiani A, Gramegna M, et al. Development of a nested PCR assay for detection of feline infectious peritonitis virus in clinical specimens. J Clin Microbiol 1997; 35(3): 673-675.

83. Hohdatsu T, Yamda M, Okada M, et al. Detection of feline immunodeficiency proviral DNA in peripheral blood lymphocytes by the polymerase chain reaction. Vet Microbiol 1992; 30: 113-123.

84. Jackson ML, Haines DM, Meric SM, et al. Feline leukemia virus detection by immunohistochemistry and polymerase chain reaction in formalin-fixed, paraffinembedded tumor tissue from cats with lymphosarcoma. Can J Vet Res 1993; 57: 269-276.

85. Jackson ML, Haines DM, Taylor SM, et al. Feline leukemia virus detection by ELISA and PCR in peripheral blood from 68 cats with high, moderate, or low suspicion of having FeLV-related disease. J Vet Diagn Invest 1996; 8: 25-30. 
86. Miyazawa T, Jarrett O. Feline leukaemia virus proviral DNA detected by polymerase chain reaction in antigenemic but non-viraemic ('discordant') cats. Arch Virol 1997; 142: 323-332.

87. Sykes JE, Studdert VP, Anderson G, et al. Comparison of Chlamydia psittaci from cats with upper respiratory tract disease by polymerase chain reaction analysis of the ompA gene. Vet Rec 1997; 140(12): 310-313.

88. Benveniste RE, Sherr CJ, Todaro GJ. Evoluation of type C viral genes: origin of feline leukemia virus. Science 1975; 190: 886-888.

89. Casey JW, Roach A, Mullins JI, et al. The U3 portion of feline leukemia virus DNA identifies horizontally acquired proviruses in leukemic cats. Proc Natl Acad Sci USA 1981: 7778-7782.

90. Fulton R, Plumb M, Shield L, et al. Structural diversity and nuclear protein binding sites in the long terminal repeats of feline leukemia virus. $J$ Virol 1990; 64(4): 1675-1682.

91. Larsson LI. Immunocytochemistry: Theory and practice. Boca Raton, FL.: CRC Press, 1988.

92. Haines DM, Chelack BJ. Technical considerations for developing enzyme immunohistochemical staining procedures on formalin-fixed paraffin-embedded tissues for diagnostic pathology. J Vet Diagn Invest 1991; 3: 101-112.

93. Hsu SM, Raine L, Fanger H. The use of avidin-biotin peroxidase complex in immunoperoxidase techniques. Am Clin Pathol 1981; 75: 816-861.

94. Hoover EA, Mathes LE, Rojko JL, et al. Modifications of the immunofluorescence assay for feline leukemia virus group-specific antigens. Am J Vet Res 1978; 39(12): 1877-1880.

95. Noordhuizen JPTM, Frankena K, van der Hoofd CM, et al. Application of Quantitative Methods in Veterinary Epidemiology. Wageningen: Wageningen Pers, 1997; 81-82.

96. Madewell BR, Jarret O. Recovery of feline leukaemia virus from nonviraemic cats. Vet Rec 1983; 112: 339-342. 
97. Pacitti AM, Jarret O. Duration of the latent state in feline leukaemia virus infections. Vet Rec 1985; 117: 472-474. 
Table 1 - Summary of ELISA, IFA, PCR and IHC results for all cats.

\begin{tabular}{|c|c|c|c|c|}
\hline Number of Cats & $\begin{array}{l}\text { ELISA Results } \\
\text { Peripheral Blood }\end{array}$ & $\begin{array}{c}\text { IFA Results } \\
\text { Peripheral Blood }\end{array}$ & $\begin{array}{c}\text { PCR Results } \\
\text { Cornea }\end{array}$ & $\begin{array}{l}\text { IHC Results } \\
\text { Cornea }\end{array}$ \\
\hline $\mathrm{n}=7$ & Pos & Pos & Pos & Pos \\
\hline $\mathrm{n}=3$ & Pos & Pos & Pos & $\mathrm{Neg}$ \\
\hline $\mathrm{n}=1$ & Pos & Pos & Neg & Pos \\
\hline $\mathrm{n}=1$ & Pos & Pos & $\mathrm{Neg}$ & $\mathrm{Neg}$ \\
\hline $\mathrm{n}=3$ & Pos & $\mathrm{Neg}$ & $\mathrm{Neg}$ & $\mathrm{Neg}$ \\
\hline $\mathrm{n}=1$ & Pos & Ind & $\mathrm{Neg}$ & $\mathrm{Neg}$ \\
\hline $\mathrm{n}=1$ & Pos & Ind & Pos & $\mathrm{Neg}$ \\
\hline $\mathrm{n}=17$ & $\mathrm{Neg}$ & NP & $\mathrm{Neg}$ & $\mathrm{Neg}$ \\
\hline \multicolumn{5}{|c|}{$\begin{array}{l}\text { ELISA = Enzyme linked immunosorbent assay, IFA = immunofluorescence antibody, } \\
\text { PCR = polymerase chain reaction, IHC = immunohistochemical } \\
\text { Pos = positive, Neg = negative, Ind = indeterminate, } N P=\text { not performed }\end{array}$} \\
\hline
\end{tabular}


Table 2 - Statistical analysis of agreement of test results in all cats.

\begin{tabular}{|lrrrrrr|}
\hline & $\begin{array}{c}\text { ELISA } \\
\text { Positive }\end{array}$ & $\begin{array}{c}\text { ELISA } \\
\text { Negative }\end{array}$ & $\begin{array}{c}\text { IHC } \\
\text { Positive }\end{array}$ & $\begin{array}{c}\text { IHC } \\
\text { Negative }\end{array}$ & $\begin{array}{c}\text { IFA } \\
\text { Positive }\end{array}$ & $\begin{array}{c}\text { IFA } \\
\text { Negative }\end{array}$ \\
\hline PCR Positive & 11 & 0 & 8 & 3 & 10 & 0 \\
PCR Negative & 6 & 17 & 1 & 5 & 2 & 3 \\
Kappa value & $\mathrm{k}=0.65$ & & $\mathrm{k}=0.52$ & & $\mathrm{k}=0.67$ & \\
\hline IHC Positive & 9 & 0 & & & 4 & 3 \\
IHC Negative & 8 & 17 & & $\mathrm{k}=0.44$ & \\
Kappa value & $\mathrm{k}=0.53$ & $\mathrm{ND}$ & & \\
\hline Numbers correspond to number of cats with a given test result. & & & \\
\hline
\end{tabular}




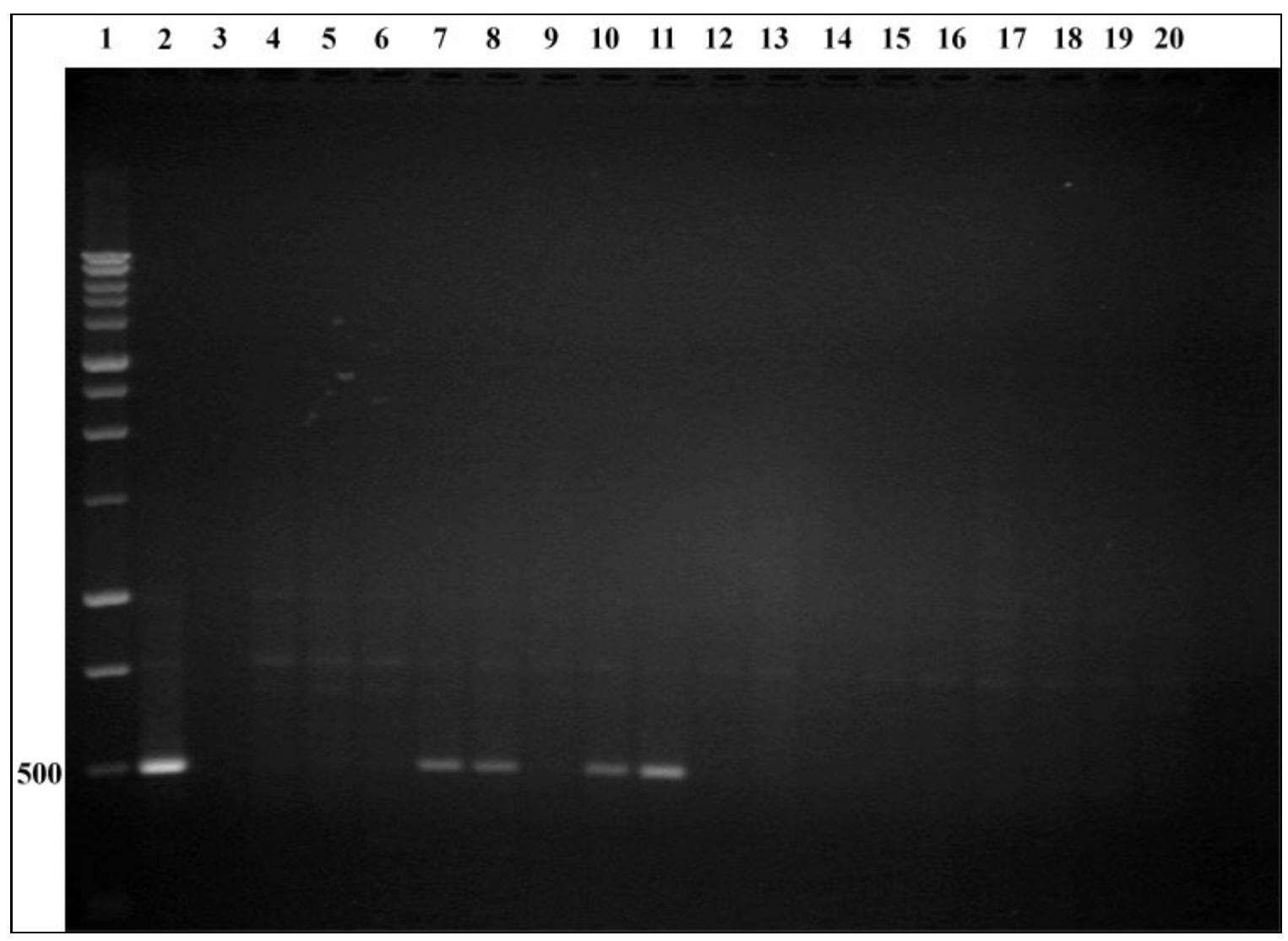

Figure 1. Agarose gel of PCR products. 500 bp marker on DNA ladder is labeled. Bands at 495 bp level are representative of FeLV target sequence. Lanes 2, 6, 7, 9, and 10 were considered positive.

Lanes

1. DNA ladder

11. FeLV 9

2. FL74 positive control

12. Control 1

3. Blank negative control

13. Control 2

4. FeLV 1

5. FeLV 2

14. Control 3

15. Control 4

6. FeLV 3

16. Control 5

7. FeLV 4

8. FeLV 5

9. FeLV 6

10. FeLV 7

17. Control 6

18. Control 7

19. Control 8

20. Control 9 


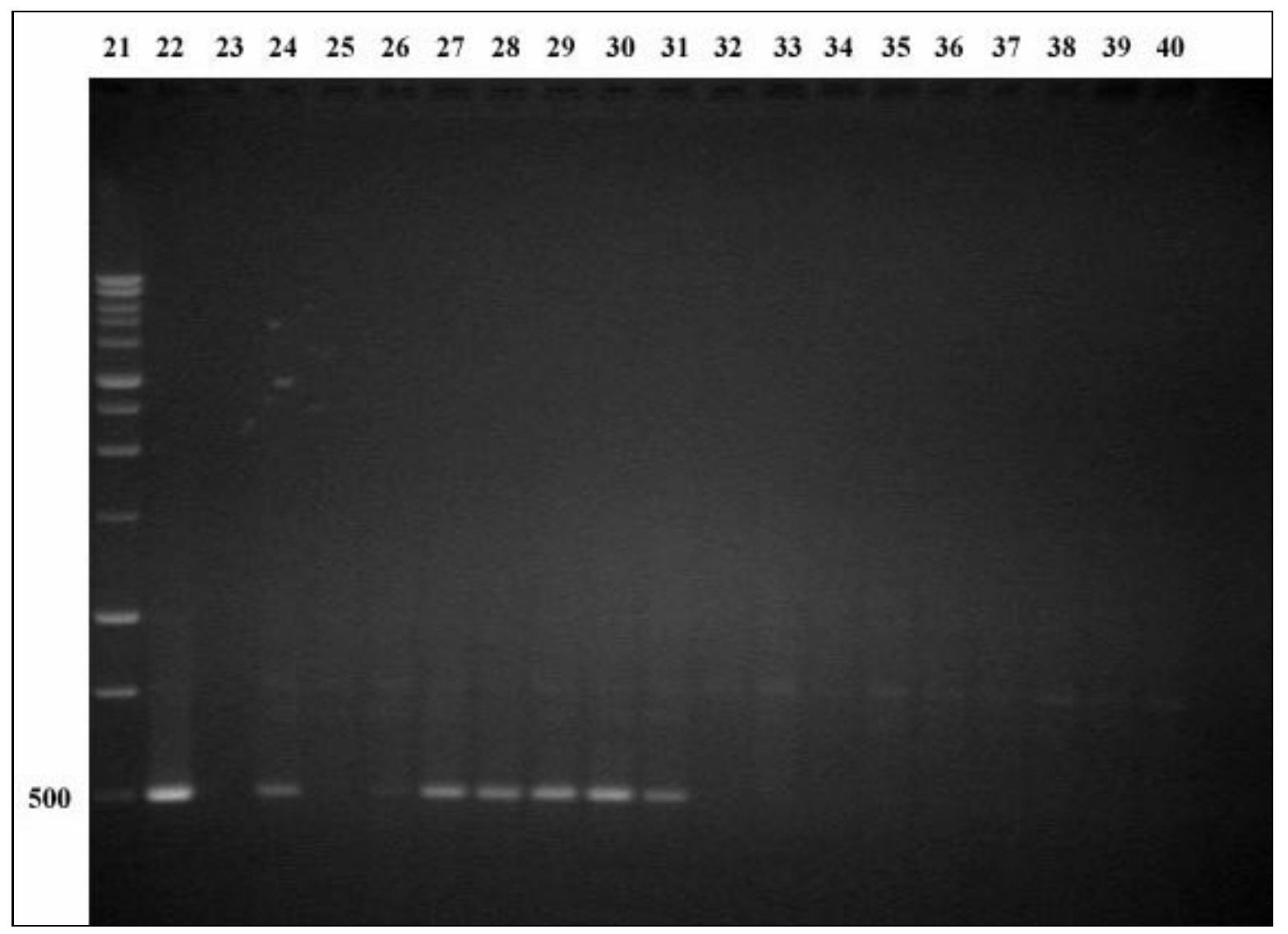

Figure 2. Agarose gel of PCR products. $500 \mathrm{bp}$ DNA marker is labeled. Bands at $495 \mathrm{bp}$ level are representative of FeLV target sequence. Lanes 2, 4, 6, 7, 8, 9, 10, and 11 were considered positive. Lanes

21. DNA ladder

31. FeLV 18

22. FL74 positive control

32. FeLV 19

23. Blank negative control

33. Control 10

24. FeLV 11

25. FeLV 12

34. Control 11

35. Control 12

26. FeLV 13

36. Control 13

27. FeLV 14

28. FeLV 15

29. FeLV 16

30. FeLV 17

37. Control 14

38. Control 15

39. Control 16

40. Control 17 


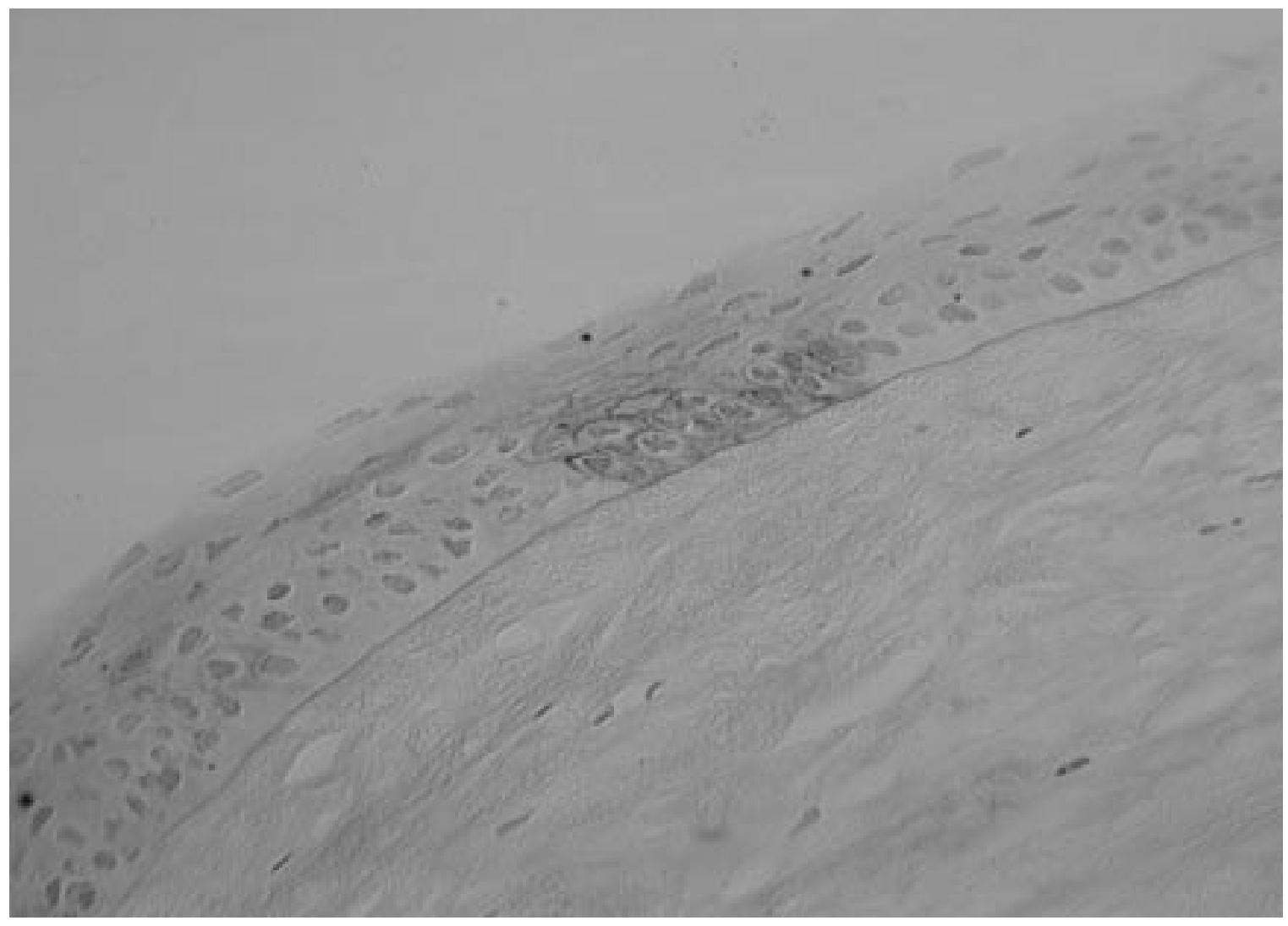

Figure 3. Corneal section from an ELISA positive FeLV cat. Positive IHC staining is localized to the corneal epithelium. Corneal stroma is devoid of specific staining (400x magnification with hematoxylin counterstain). 


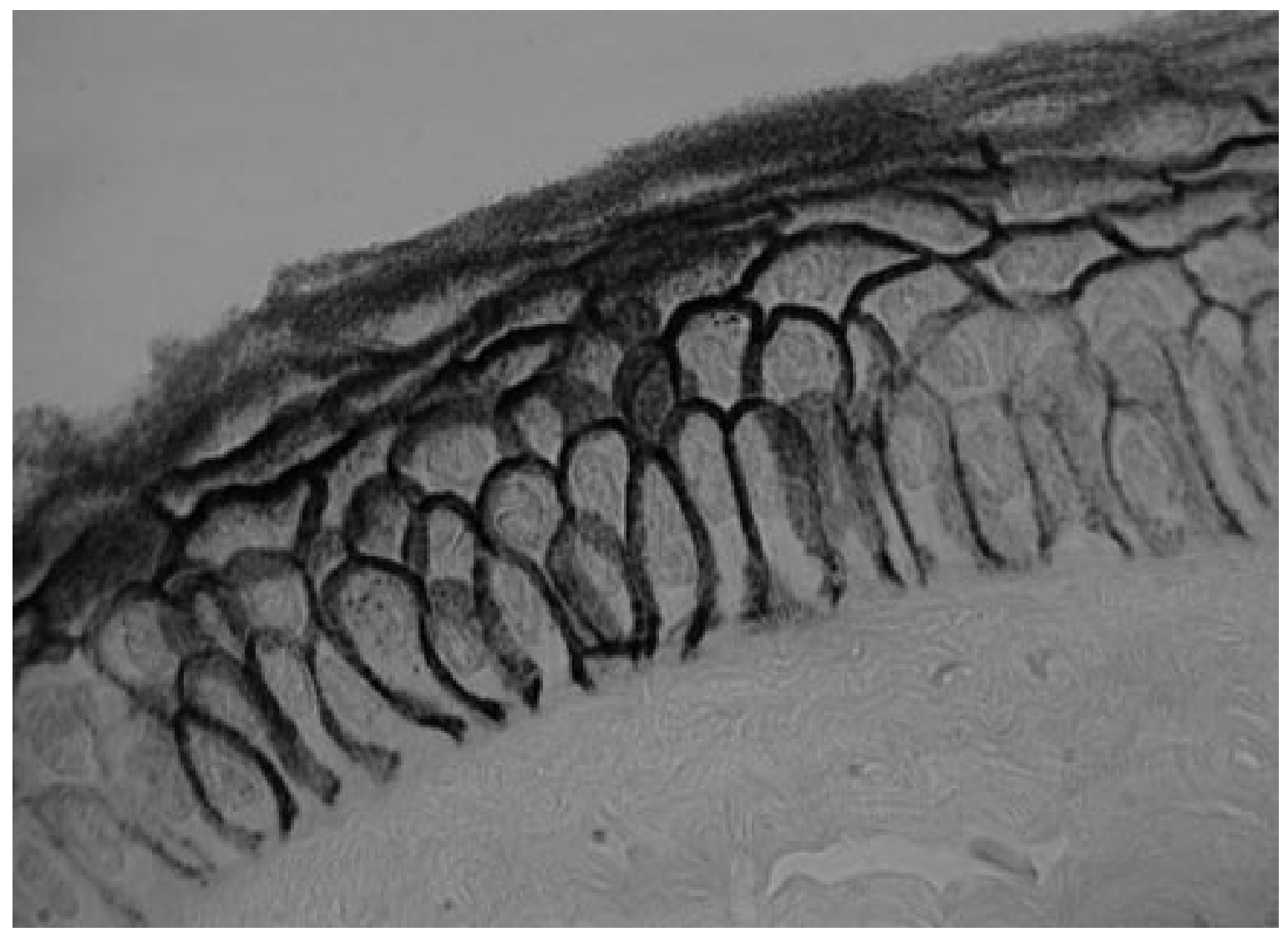

Figure 4. Corneal section of an ELISA positive FeLV cat. Specific IHC staining is localized to corneal epithelial cell surfaces (1000x magnification with hematoxylin counterstain). 


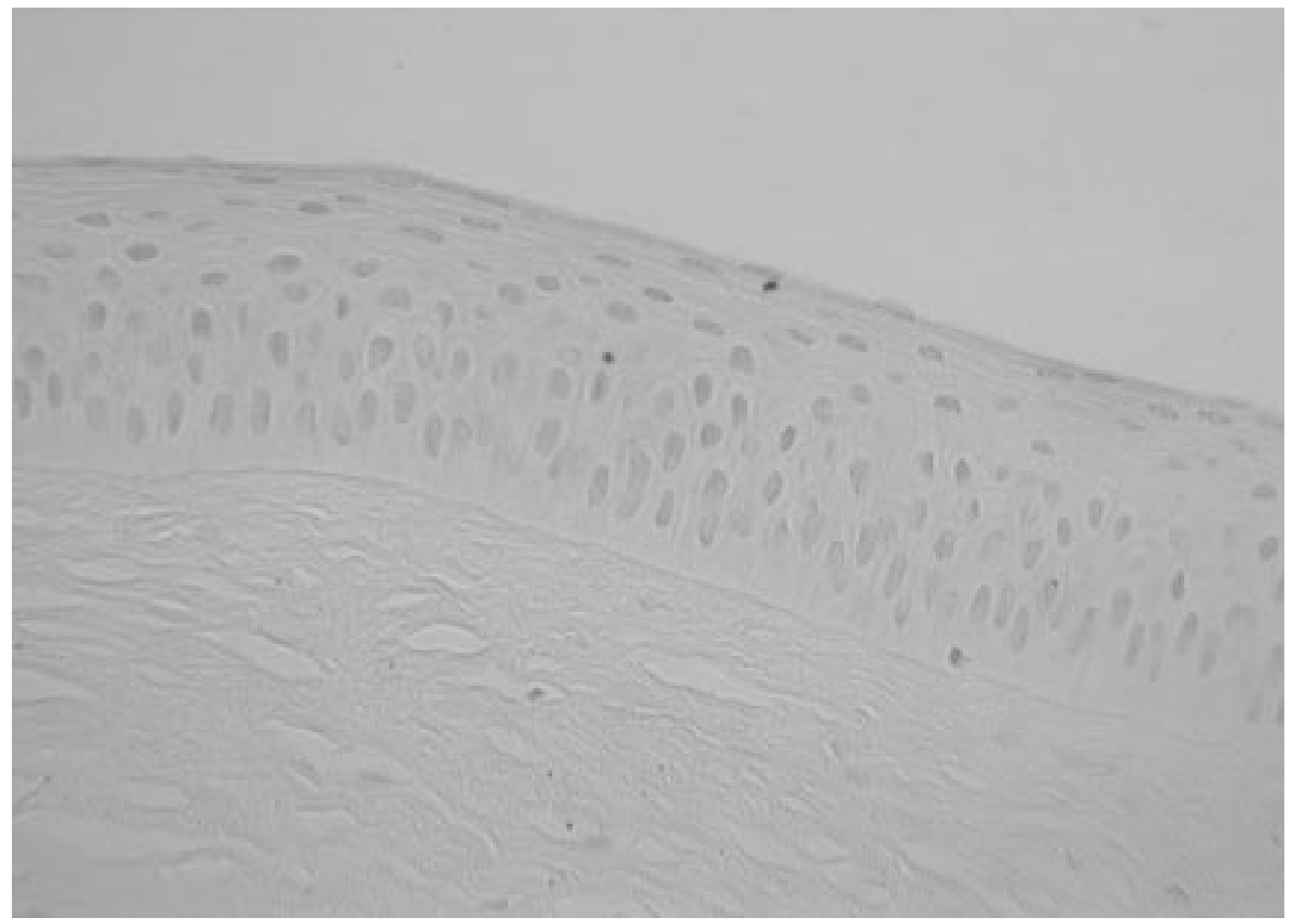

Figure 5. Corneal section from an ELISA negative cat. No specific IHC staining is present (400x magnification with hematoxylin counterstain). 


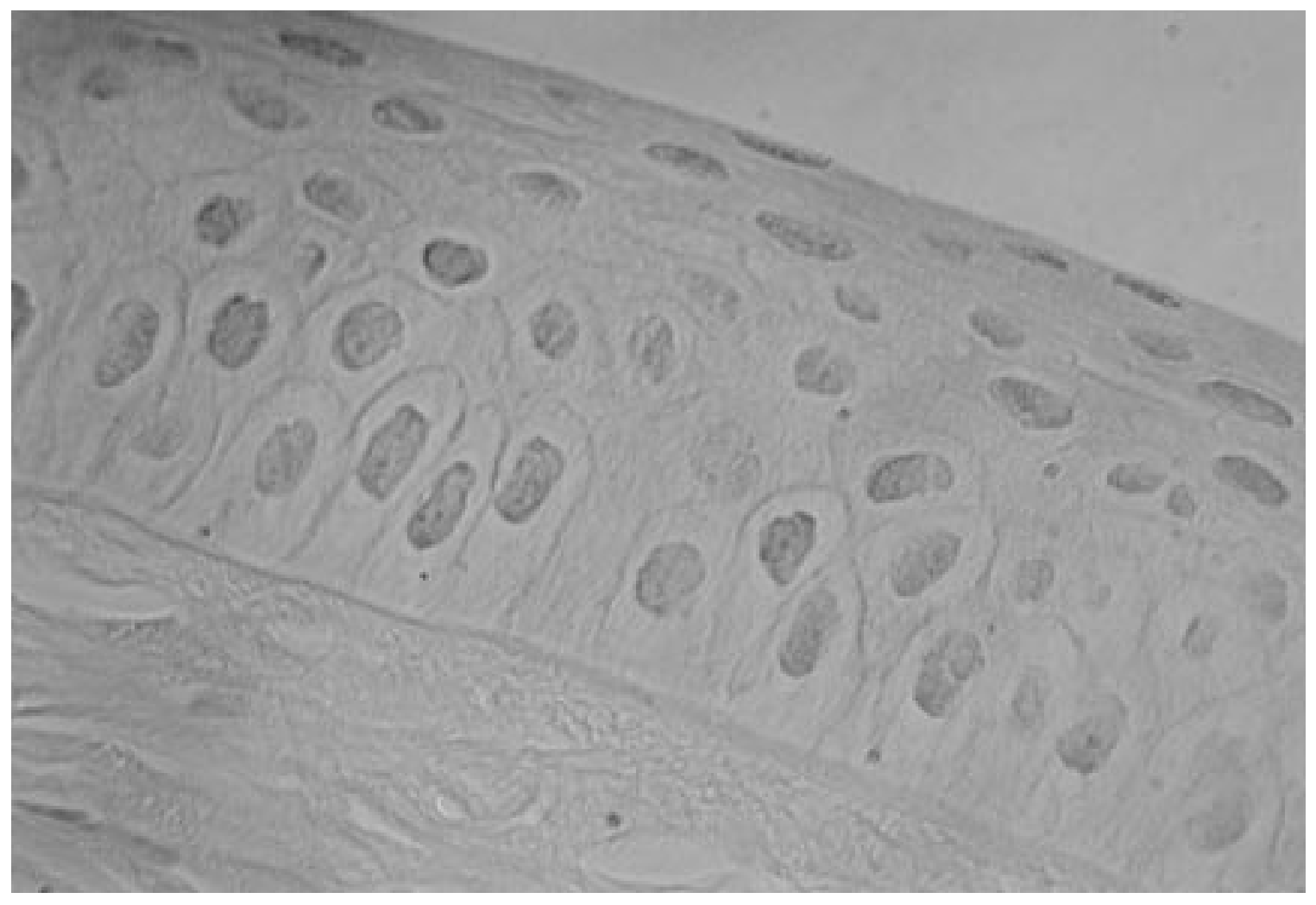

Figure 6. Corneal section from an ELISA negative cat. No specific IHC staining is present (1000x magnification with hematoxylin counterstain). 


\section{Appendix A}

Scale for interpretation of kappa statistic values, the chance-corrected probability of agreement between 2 tests.

$\underline{\text { K Value }}$

0

$0.01-0.20$

$0.21-0.40$

$0.41-0.60$

0.61-0.80

$0.81-0.99$

1.00
Strength of Agreement

No better than chance

Slight

Fair

Moderate

Substantial

Almost perfect

Perfect 


\section{VITA}

Ian P. Herring was born on January 17, 1966 in Coral Gables, FL. He lived in Canal Zone and Republic of Panama from the ages of 2 to 19. Undergraduate studies and veterinary training were pursued at Texas A\&M University. After obtaining his D.V.M. from Texas A\&M in 1994, he completed an internship in Small Animal Medicine and Surgery at the VA-MD Regional College of Veterinary Medicine. He is currently completing residency training in veterinary ophthalmology at the VA-MD Regional College of Veterinary Medicine, after which he will remain there as a clinical instructor in ophthalmology. 